\title{
Porous infrastructures and the politics of upward mobility in Brazil's public housing
}

\author{
MPIfG Journal Article \\ Moisés Kopper: Porous Infrastructures and the Politics of Upward Mobility in Brazil's Public Housing. In: Economic Anthropology 6(1), \\ 73-85 (2019). Wiley-Blackwell \\ The MPIfG Journal Articles series features articles by MPIfG researchers and visiting scholars published in peer-reviewed journals. \\ Max Planck Institute for the Study of Societies (MPIfG) Cologne | www.mpifg.de
}

Moisés Kopper

Max Planck Institute for the Study of Societies, 50676 Cologne, Germany

Corresponding author: Moisés Kopper; e-mail: moiseskopper@gmail.com

In Brazil's post-neoliberal government of upward mobility and public policies, infrastructures are the symbiosis of experimental forms of government, political action, and practices of consumption. This article draws from a four-year-long multiscalar ethnography of Minha Casa Minha Vida, the country's largest public housing program. It uncovers the temporalities of infrastructural hope unleashed as people wait for-and engage with - their first homeownership. Specifically, I focus on struggles over the design and implementation of surveillance and security technologies by residents of one such condominium, charting how aspirations for "the good life" crystallize in emerging-yet ephemeral_collectives of consumer-citizens. My contention is that desires for infrastructure elucidate the ubiquity and ever-elusiveness of middle-class affects in Latin American social mobility. The tangled worlds of desire and materials illuminate the workings of a middle-class sensorial: the topography of images and affects through which class mobility is experienced and located in time and space. Trailing the movement, saturation and porosity of housing materialities and their embroilment with emergent forms of sociality decode the ambiguous economic and political subjectivities flourishing in the aftermath of fraught urban interventions.

Keywords Infrastructure; Well-being; Housing Policies; Class Mobility; Brazil

The gate had just closed before my eyes. I was bewildered and for minutes did not know how to react. After four years of devoted fieldwork conducted among low-income residents of a housing project in the city of Porto Alegre in southern Brazil, I had come to know the nitty-gritty of their everyday lives - their neighborhood quandaries, frustrated expectations, and forsaken aspirations. I moved freely across the public and private domains where upward mobility was architected: from the regular meetings of Codespa-a housing association that has been convening hundreds of members since 2009-to the secluded apartments and collective areas of the residential project inaugurated in September 2014.

Yet, amid these social, economic, and political realities in flux, my access was interrupted by the workings of a newly designed security apparatus. A garage door with remote activation had been put in place, along with surveillance cameras and a walkthrough gate triggered by electronic magnets that were now being individually carried by the residents on their key chains. From behind the overwhelming structure of iron, cement, and infrareds, a man in uniform gloated over my dumbfoundedness. "Here nobody enters without the express consent of the building manager, not even a probation officer!" (personal communication, February 28, 2017). The new security officer was adamant and inspected the computer to ensure the scene was being properly recorded.

A strange déjà vu occurred on that blistering afternoon in February 2017. Coming from an academic background in Latin American urban ethnography, I had seen such security technologies all over the countless fortified, upper-middle-class condominiums in Brazil's big cities, but its pervasive presence in social housing projects that were by and large advertised as the ultimate poverty antidote caught me off-guard. Here I follow the trail of this newly developed surveillance apparatus as it unfolds and saturates life and sociality in the aftermath of a Minha Casa Minha Vida residential project. 


\section{Kopper}

The empirical evidence I present is part of wider research conducted between 2012 and 2017 among a model community of politically engaged first-time homeowners. Through multisited ethnographic work, long-term conversations, and sequential survey data collection, I interrogated the politics of well-being and alternative modes of stratification that flourished as my interlocutors transitioned from periurban informal settlements to middle-class environments.

Drawing on these material encounters, the article asks, how does the transformed architecture of these public-private infrastructures help illuminate the long-term effects of fraught urban interventions? What emerging sites of imagination and belonging are abetted or forfeited as subjectivities enmesh with place making? Articulating vernacular ideas of well-being with the contentious temporalities of waiting and hoping for the promises of private infrastructure, I develop a retooled, ethnographically informed approach to Latin American class mobility - one that considers the interplay of distinction, aspiration, and experimentation in the making of ever-elusive middle-class worlds.

This article is divided into five parts. I first locate concerns about securitization within a shifting affective landscape of privatized urban infrastructure. As enclaved residential formations travel from upper-middle-class environments and become a feature of public housing projects, they reshuffle the spectrum of class positionalities within Brazilian society. I then return to the condominium in Porto Alegre, reconstructing the cultivation of security designs through the lens of Rodrigo, a young male in charge of the building administration. Articulating personal desires for self-improvement to the ever-changing worlds of material hope, his trajectory illuminates how infrastructures congeal as both indexes of participation and plateaus for the good life. The next section further attends to the porosity of infrastructures, exploring the transitions and novel forms of sociality made possible by surveillance systems, as people remake their lives in the condominium. A last section discusses some of the implications of thinking of infrastructures as vectors of aspiration and desire for an alternative approach to middle-class makings in anthropological scholarship.

\section{The political economy of first-time homeownership}

First-time homeownership was made a reality for millions of low-income families by Minha Casa Minha Vida, Brazil's nationwide housing initiative launched in 2009. Under the administrations of the left-leaning Workers' Party (PT; 2003-16), Brazil's economy grew steadily alongside income redistribution. Wage increases, controlled inflation, credit expansion, and major economic and social policies paved the way for the uplifting of millions of low-income Brazilians into what was once heralded as the country's "new middle class" (Klein, Mitchell, and Junge 2018; Kopper and Damo 2018) - a process that experienced significant rollbacks in ensuing years as the economy plunged into recession.

Minha Casa Minha Vida was tasked with constructing 3.4 million homes, becoming a hallmark of PT's post-neoliberal poverty governance via inclusive consumption. The initiative was part of a multibillion-dollar effort to infrastructurally upgrade and modernize the nation's big ailing cities, long plagued by corruption and uneven distribution of public resources. Workable infrastructures (as 2013 street upheavals made clear) are a key form of inhabiting the city and experiencing citizenship for the largest part of the population daily counting on and yearning for public investments in education, transportation, health, and security.

By 2016, large-scale mortgage subsidies had been issued to nearly 4 million families earning up to three minimum wages a month (approximately US\$650 in 2009), ${ }^{1}$ while another US\$2 billion were allocated to Minha Casa Melhor, a governmental credit line through which beneficiaries gained access to low-interest loans to furnish their apartments. By injecting dozens of billions of dollars into the economy, the program supported both beneficiaries and investors, successfully revamping the construction industry and encouraging mass consumption through a secure (if unviably long-term) credit platform. 
Traveling through the local arms of the state, housing benefits and their implementation hinged vastly on local "architectures of participation," by which I refer to the contentious political terrains - beset by community leaders, politicians, social workers, urban planners, and representatives of public banks - through which the housing program gained traction. Under the guise of state accountability and transparency, direct channels between the government and housing movements were crafted, encouraging potential beneficiaries to partake in bottom-up grassroots politics.

Locally administrated housing projects abided by an overarching architectural plot determined at the national level by Caixa Econômica Federal, the public bank upholding endorsements, financing construction, and issuing mortgages. "These buildings are required by law to include multisport game courts, party salons, and several facilities, such as plazas and benches, to foster conviviality" (interview, December 10, 2013, Porto Alegre) - I was told by architect Debora Fará, an employee of a real estate developer specializing in social housing. On top of such prerequisites, the bank's science and technology committee deliberates over the types of construction blocks allowed. "They all look the same. In order to rationalize costs, very little can be changed architecturally," Debora confessed. "Our job is to make the largest number of two-dormitory, forty-square-metered units fit into awkwardly shaped and sometimes unwieldy plots of land donated by municipalities" (interview, December 10, 2013, Porto Alegre).

Through their particular design as fenced conglomerates, Minha Casa Minha Vida projects intended to build purified and disciplined communities that could enhance the lives of their inhabitants. In the long run, because of their moral underpinnings, such projects were expected also to improve social statistics, lowering violence and crime rates. ${ }^{2}$ As technologies of governance seeking to restore underprivileged collectives into the societal fabric, they differed from upper-middle-class fortified enclaves and their quest for isolation in Brazil's urban landscape.

Widely studied as they sprawled over Latin American wealthy suburbs in the 1970s and 1980s, fortified enclaves grew to include private schools, hospitals, and entertainment centers, thus becoming statements of distinction, personality, privacy, and class prestige. Anthropologist Teresa Caldeira $(2000,258)$ defined them as zones of social and physical segregation that "emphasize the value of what is private and restricted [over] ... what is public and open in the city." In Caldeira's model, fortified enclaves are malleable infrastructures that operate through invisible, privatized, and networked forms of services. By shaping everyday forms of sociability and seclusion, gates and fences protect and craft distinctions - both symbolic and geographic - in the name of security. Because they are engineered to separate, they enable a normalizing meritocratic hierarchy of successful and deserving individuals, equalized through the property's market value.

In what follows, I examine how such infrastructures traveled to become distinctive features of low-income housing in contemporary Brazil. What do fences stand for? How is the boundary between public and private spaces constantly renegotiated in the aftermath of housing projects? I will argue that while material similarities witness the continuum and pervasiveness of class affects in an utmost asymmetrical society, their workings, usages, and subjective outcomes are variable and up for grabs. To fully grasp the role and functioning of these porous infrastructures, we need to advance new understandings of the intricate interplay between material technologies, middle-class longings, and emerging collectives of citizen-consumers. This will lead to a fuller picture of the dynamics of inclusion and distinction at play among once rising urban poor in contemporary Brazil.

\section{Local economies of hope}

I had already run into the new security officer - a retired police officer in his sixties - a month before while applying a survey aimed at tracking the condominium's social, economic, and demographic transformations over time. In our brief interaction that day, he prompted a conversation on how to distinguish the "vagabond" from the "hard worker." Softening his voice and pointing to the horizon, he alluded to the free circulation of drug packages (pacotinhos) through corridors and common areas. "They all originate from the hills behind us. Small thieves and traffickers breed 


\section{Kopper}

there and come to hide among us. They are like pigs: They can't survive outside the mud" (personal communication, February 28, 2017).

Stuck at the gate, my recollections of that first encounter suddenly became vivid. Against the backdrop of an interconnected drug business, the gatekeeper perceived his job as one of separating, purifying, and enforcing discontinuations - symbolic and moral-materialized in the presence of gate structures. In a book, he kept an individualized log of the flux of people. Strict control of the ins and outs was crucial, I was told. A detailed report was to be presented at the end of the day to the building manager. "It is nothing personal," he insisted. "When I first got here, chaos was all there was. I had never seen anything like it. Youngsters arriving in clusters, strangers shouting at you: 'Let them in, they are with me.' People without education, savages who don't know how to respect" (personal communication, February 28, 2017).

In fact, the security company he worked for had been recently hired and was part of a larger plan of bringing the necessary infrastructures to the condominium, Rodrigo, a young male who had been in charge of the building administration since day one, told me. Living in an impoverished and informal settlement with his wife and child, Rodrigo had learned since an early age how to navigate the shifting terrains of precarious infrastructures, lack of opportunities, and scarce resources of Brazilian peripheries.

I met Rodrigo in 2012 in my early ethnographic forays, way before he became the spokesperson for the new kind of life envisioned by Codespa. He had a part-time job in an outsourced IT company that operated within the premises of Pontifícia Universidade Católica, a leading private university in southern Brazil. "Because of so much sorrow in one's life, you get stuck, fagged, stagnated in time. It locks you in; it becomes a burden you no longer can carry" (Rodrigo, interview, July 4, 2013, Porto Alegre). As I recall our first encounters, I realize Rodrigo had no plans to stop there.

Conversation upon conversation, I then started to piece together his larger plan of self-transformation that was under way. "I've always been hardworking; I've been through a lot. This is an opportunity to do better. Our fuel is our will to endure. This is our motivation” (Rodrigo, interview, May 5, 2014, Porto Alegre).

Rodrigo took a break to gather his thoughts. "There was a time ... when I arrived, I used to spoil the environment. I am no longer that person. These days, I strive to improve my surroundings." Flashbacks from his past continued to crop up. "At some point, I dropped out of high school. I could have completed two degrees. But things did not work out. ... I never had any opportunity for anything in life, neither did these people" (Rodrigo, interview, May 5, 2014, Porto Alegre).

We were both standing in the corner of a church salon in the periphery of Porto Alegre, where a crowded housing meeting was taking place. Rodrigo gazed one more time over the three hundred people sitting in carefully aligned chairs. "With a house, $50 \%$ of your life is settled. We can catch up on the rest through effort and hard work. But an unstable home doesn't get you anywhere. Which is why we have to work to prepare these families to move in and to live on, every day of their new lives" (Rodrigo, interview, May 5, 2014, Porto Alegre).

Like Rodrigo, the people in the audience did not blink, listening to every word coming from the restless voices of local leaders. Again, his thoughts carried him back a few years to the defining encounters when those same community leaders summoned residents of informal settlements to gather in the assemblage of Codespa. As I would later discover, random forays aimed at bringing in new associates were common but peaked during the 2012 municipal elections, when one of the leaders ran for a position in the city council.

I heard from members who had been through the screening that leaders actively looked for signs of social and economic vulnerability. These included multiple families living under the same roof, degraded hygienic conditions, and a lack of basic public infrastructure like sewage, water, and electricity. Over time, hundreds of disadvantaged and underrepresented urban poor - way beyond the program's local capacity - were lumped together and strategically deployed by leaders to represent the diacritical signals of deprivation and poverty that would ultimately garner access to the scarce public benefit. 
"They found me in my house and saw something in me," Rodrigo continued talking about the sparkle of ambition and creativity that kept him active against all odds (interview, July 4, 2013, Porto Alegre). Though not particularly skilled with oratory, his IT knowledge qualified him early on to occupy a seat on the association's board. Over the span of two years, Rodrigo was tasked with devising new computer technology capable of keeping track of and managing the hundreds of members Codespa was gathering in the outskirts of Porto Alegre.

By early 2014, with his help, hope had materialized into new forms of technological belonging (Anand 2017). Meetings were documented through sign-in logs and written records, membership cards with pictures and personal information were issued to all participants, and elaborate bookkeeping registers controlled the members' monthly payments that kept the association afloat. To foster transparency and verify the righteousness of claims to housing, proceduralism was amassed with random visits to members' residences.

These participatory infrastructures spread into complex calculations of inclusion and exclusion, creating a material channel for the circulation of "information" (Gupta 2012; Hetherington 2012; Hull 2012; Kopper 2016). As networked forms of knowledge shared during the housing meetings with the intent to guide sociality within the new space, information remained simultaneously vague and quantifiable. It was wrapped in the development and perfection of practical skills - such as how to separate trash, how to manage household finances, how to become a microentrepreneur - and in a series of lectures on what constituted adequate social behavior. Through its flow and usage, information became a proxy for subjective transformation amid the everyday uncertainties of waiting for homeownership.

People's efforts to earn a house by making themselves visible in these new bureaucratic structures became the source of Rodrigo's endeavor to develop better and more complex computational systems. Over time, I learned that he thought of these devices as vessels for the circulation of hope. By encapsulating the moral efforts required to become deserving of the housing benefit, such participatory infrastructures would allow for a fair screening of the beneficiaries and would therefore lead to the model community Rodrigo had envisaged for Codespa in the aftermath of the public policy.

"This project unleashed the best in me. It's like cleaning the dust off a person. Roll up your sleeves and go! This is how I felt," he told me a few days before moving (Rodrigo, interview, August 26, 2014, Porto Alegre). In the everyday temporalities of waiting and hoping, Rodrigo's resilient philosophy blended political opportunity with locally crafted longings for self-improvement. This embroilment would soon be put to work in the assemblage of a new collective: the condominium.

\section{Material sociality}

Eventually, over the course of our interactions, Rodrigo became employed by information technology companies in the wealthier parts of the city. Around the same time, in late 2014, he was publicly acclaimed building manager by Codespa's leaders. Rodrigo took this as an opportunity to hone his project of transforming the condominium into a self-sustainable model community.

Shortly after moving into the condominium, he told me,

I am here today. It was a matter of luck. Sometimes we are just waiting for one [encouraging] word, an opening that allows one to continue. In my life, these things came together. I learned the political significance of our work as an "organized civil society" acting upon a "structure of governance." Helping others, I helped myself. I feel like I am a more mature person. (Rodrigo, interview, January 29, 2015)

As building manager, Rodrigo kept himself busy running between corridors, yards, and residents in the hope of anticipating problems and formulating solutions. It was difficult to find him in his own apartment. Instead, 
our conversations took place in hallways or at construction sites and focused on the outcomes of condominium meetings, calculations of condominium fees, and default projections related to those fees:

There is a lot going on in my mind. A lot to do. I don't know if I'm gonna be here tomorrow. If it were up to me, I would be in an even better place. To have a chance to upgrade the standards of our community. ... Each of us has a ten-year mortgage. This means ten years that we have to stay before we move up again. Like a clock, ticking ... toward the future. (Rodrigo, interview, January 29, 2015)

By surveilling the unfolding of life in the project, Rodrigo gained a practical sense of how people navigated this new terrain, the extent to which they were adapting to collective norms, and the plasticity needed to set these measures in practice. He also monitored people's usage of collective infrastructures like playgrounds and plazas. Although standard in the design of Minha Casa Minha Vida projects, many of these devices remained a novelty for dwellers.

With a fully sketched intervention plan in mind, Rodrigo first approached the adolescents who had increasingly become known for their "inappropriate public behavior" and late-night roughhousing (farra) on the community soccer field. "I pierced into their world, made myself one of them and gained their trust" (Rodrigo, interview, September 22, 2016). Once familiarized with their habits and language, he leveraged this knowledge with their parents, summoning them to reinforce the condominium bylaws and to regain parental control in the process.

For months, Rodrigo continued what he called "ant work," alluring residents to partake in activities like recycling and landscaping. "The idea is to move up the social ladder, but people are not yet aware of this goal," he told me in September 2016, two years into his role as building manager (Rodrigo, interview, September 22, 2016). Meanwhile, administrative issues and sociability predicaments escalated. His work with adolescents did not yield the expected results; a growing number of defaulters had reduced the condominium's revenues; service providers were too expensive and inefficient; and rising antagonisms between Rodrigo, community leaders, and residents thwarted his decision-making.

To tackle such problems at once, Rodrigo came up with the idea to deploy interconnected security and surveillance devices. After receiving expensive quotes, he convinced the residents to assist with the installation of video doorbell phones. While groups opened makeshift holes in the ground for the flow of wires, he closed a deal with a cable internet provider, which agreed to provide free fiber-optic infrastructure in exchange for advertising its services. The heart of this communication system was set up in the recently constructed sentry box near the gate and was overseen by functionaries of a newly contracted security company like the one I had encountered on my way to the residences.

One more time, Rodrigo justified the adoption of these measures by comparing the condominium to an enterprise. Like functionaries who are only allowed to circulate within the premises of a corporate building by wearing identification badges, the condominium's residents had to now permanently carry their magnetic tags with them; cars had to bear a sticker to be granted access by the security personnel; and new, upcoming technologies, such as infrared cameras and LED lights, were going to assure the dwellers that the complex's boundaries remained safe.

By actively filtering and ultimately separating those who could pass from those who had to remain outside, such porous technologies revealed more than the making of a new sociability arbitrated by objects. As vessels for new senses of normalcy, desire, and well-being, they also fetched a matrix of legibility for how things ought to be in the everyday architecture of the project. Through trial and error, experimental technologies could pave the way for modernity, while setting the limits for collective and private aspiration. "We still need ergonomic chairs, tables, coffeemakers, microwaves, and cabinets to furnish the common areas with the necessary comfort that will set the standard for how things ought to be" (Rodrigo, personal communication, January 18, 2017). 
Deeply entrenched in place making, materialities were conceived to unravel new imaginative horizons (Crapanzano 2004) and senses of well-being (Fischer 2014; Mathews and Izquierdo 2009). Meanwhile, Rodrigo kept "budgeting and quoting," making dreams fit into concrete, financially viable projects. "I am still calculating to see what is feasible. I will need the residents' support. To push things. To install” (Rodrigo, personal communication, January 18, 2017).

"This is the idea," I heard from him in our last conversation in 2017. "It's something they are not quite seeing today, but they will” (Rodrigo, personal communication, February 28, 2017). Rodrigo's words deeply resonated with those I had heard two years earlier and made me think of the potential to architect futures and senses of normalcy through the imagination of infrastructures. "Sometimes I get compliments by outsiders who tell me, 'Rodrigo, there are many middle-class high-rises that don't have all this infrastructure.' This makes my day. We are not lagging that much behind, after all” (Rodrigo, personal communication, February 28, 2017).

\section{Blurred frontiers, movements for aspiration}

To many people with whom I spoke during my "gate ethnography," unpredictability and day-to-day uncertainties stemmed exactly from the murky politics of the inside. "Are you the one doing research?" (personal communication, February 28, 2017), Dona Maria asked; the lady in her sixties entered the building with grocery bags. "There is nothing wrong here; I can't say any more." A brief silence unfolded; after a long breath, she continued, "There are many who complain, but I don't see things that way. Of course, last week two motorcycles were stolen inside the condo, but they did me no harm. As long as you don't mess with them, everything should be fine." One day, the woman expressed concern about a significant number of units being occupied by relatives of community leaders. "They pulled the rug [puxaram o tapete] - they rattled her cage - Then I learned the secret is to never question. I need this to work out for me. Otherwise, where am I to go?" (Dona Maria, personal communication, February 28, 2017).

Such a concern was decidedly not one of Tio Paulinho's - "Uncle Pauly," as he was known - a former Codespa associate who, in his own terms, left the "political veneer" behind. In our first conversation after moving, he told me,

Here, my job is to be an owner [proprietário]. We now have a voice as informed consumers of services. Where I lived before, there was no class. People were expendable. Now they are proud to use their cards and buy in stores. Even their skin looks better; they are smiling more often. All this affects your mind: you start to develop a class.

(Tio Paulinho, interview, January 22, 2015)

Tio Paulinho was one of Codespa's oldest. The sixty-year-old black man became famous after moving to the construction site in 2013 and residing in a container for months before the condominium was deemed ready for habitation. Amid debris and a makeshift office, he made himself available as a community consultant, attending to the association's members as they called or visited for updates on the construction. Known as the guardian of the collective housing dream, Tio Paulinho saw the coming together of hopes and materials from the ground up, developing an uncanny intimacy with rubble, abandoned infrastructures, and the workings of rumors in this emerging community of first-time homeowners.

As time progressed and the building materialized, Tio Paulinho was faced with even harsher deprivation. Though he had his expenses covered by Codespa, food, construction tools, and maintenance equipment were constantly stolen by squatters invested in taking over the unfinished building and claiming — for themselves - the "right" to housing.

Having worked for decades as an informal electrician, Tio Paulinho knew the importance of everyday sociability and interconnectedness in keeping his clientele satisfied and faithful. In 1975, after a severe accident that left part of his body scarred, he decided not to give up and instead became a community leader. As Tio Paulinho's professional networks overlapped with his local political activities, he sought to provide infrastructural improvements, including 
street pavement, to his community. Simultaneously partaking in the city's Participatory Budget and relying on political brokerages, he harnessed communal circuits of mutual aid while coordinating land occupation on vacant properties. Enacting his own redistributive politics (Ferguson 2015), he allotted the land to twenty-five activist families and demanded public services by way of water, sewage, and electrical infrastructure.

Navigating the margins of the state and its legal frames (Das and Poole 2004), Tio Paulinho saw his role as a proxy for public benefits that would only find its way to the disadvantaged through both citizen activism and governmental quid pro quo. Tio Paulinho's leadership in Codespa's present-day collective struggle for housing was thus a way of enshrining his painstaking community travails constructed through a lifetime of squattings and mobilizations to bring decent homes to the neediest among the poor.

In January 2015, months after the condominium's inauguration, I visited Tio Paulinho in his new apartment. Anyone familiar with his crumbling living conditions in the container would have been hard-pressed to recognize the elegantly dressed man standing before me. A comfortable environment with separated kitchen and living areas, crowded with technological objects - among which was a television, a washing machine, and various kitchen appliances - emerged in lieu of sand and debris. It was also the first time I was introduced to his family. Between pictures and memories, another surprise: Tio Paulinho had brought along the stray dog that kept him company while he lived by himself at the construction site. The animal was now groomed, leashed, and elevated to the condition of "pet" by his owner.

Tio Paulinho told me the chronicle of the new composition of forces within the condominium. Shortly after the inauguration, he lost access to Codespa's headquarters. Despite all odds, he remained active, circulating between common areas for most of the day, giving people advice on how to become an "apartment owner [proprietário]" and on how to adhere to condominium bylaws.

"The problem is," he reckoned, "I know all the shit." Tio Paulinho was referring to how people came to him to vent and gossip. “Today, nobody approaches [Codespa's] board anymore. They are losing popularity” (Tio Paulinho, interview, January 22, 2015). His depiction of the complicated new political and communitarian terrains upon which gate infrastructures were devised and installed helped me contextualize Dona Maria's chilling stories of persistent thievery and surreptitious nepotism as well as the encroaching spaces for critique in the condominium. Dona Maria unearthed some of the residents' concerns all the while tiptoeing around the fringes of power to preserve her acquired "right" to be a part of this community of first-time homeowners - a fragile project in itself, given the country's submersion into economic recession since 2015. In this private democracy of sorts, the role of interrogating and scrutinizing was then undermined by political expectations of infrastructures as statements of aspiration, becoming, and respectability.

Tio Paulinho became increasingly critical as his relationship with leaders started to deteriorate. He blistered their methods to select beneficiaries and questioned many of the decisions made during the implementation of the condominium. "All the 160 households are paying an extra US\$20 a month to replace lamps and windows destroyed by teenagers, but nobody is keeping track of money," he complained (Tio Paulinho, interview, January $22,2015)$. He also reported issues with overcharging and poorly executed services by the company in charge of the condominium's administration and security. "They were chosen without our consent. Where is transparency in all this?" he contested.

One day, Tio Paulinho carried on, he overheard the gatekeepers calling the project "Carandiru" - the name of Latin America's once largest prison. "They are interested in defaming; they think this is a slum.” He also deduced that the security company was sending undertrained professionals. "This person is unfit for the job; he doesn't know anybody and let's in and out without questioning." Tio Paulinho confronted the company's manager, who undermined the episode as a misunderstanding. "No!" - Tio Paulinho bellowed - “it was not. It got to everybody's ears. We are consumers of your services. We are paying you, and you give us defamation in return. Did you know we have the right to go to Procon?!" (Tio Paulinho, interview, January 22, 2015). ${ }^{3}$ 
He paused his narrative, smiled back at me, and lowered his voice. "They were not expecting me to use these fancy little words though" (Tio Paulinho, interview, January 22, 2015). The day after, three professionals secured the gate. Nevertheless, the improved service did not last for long. "It's because whoever hired them is not at liberty to complain" - he reasoned - "their hands are tied [eles estão com o rabo preso]. They plot and we suffer. That's why they were laughing."

Tio Paulinho expressed his growing criticism in an experiential language of informed consumerism. Less concerned with safeguarding the collective moral acumen once materialized in the container, his current endeavor was to identify and dodge the imperfections of this emerging low-income market-cramped with poor services and scanty chances of escaping (Hirschman 1970) - as they could potentially hamper people's aspirations for the good life. Much like Rodrigo envisioned a better place through the work of infrastructures, Tio Paulinho became the spokesperson for a critical and autonomous voice by encouraging beneficiaries to portray themselves as conscious homeowners and disciplined bill payers.

In 2017, three years after moving in, I encountered Tio Paulinho once again in his apartment. This time, he was worried about indebtedness - his and his family's. His daughter, an unemployed single mother of six, had moved to another Minha Casa Minha Vida project but was no longer able to keep up with the expenses. Tio Paulinho decided to accommodate her family until things got better. His electricity and water bills, however, tripled in cost. Meanwhile, he had been wrestling with credit card bills, growing condominium fees, and mortgages for the apartments.

As time progressed and Brazil's economy retracted, his financial situation worsened. Tio Paulinho was forced to adopt new pragmatic calculations of money allocation that ultimately reflected shifting moral regimes of value. He first prioritized the payment of water, electricity, and condominium balances. Bills directly associated with the government and the program itself — such as the credit card and the mortgage - were paid only when there was enough money left. Like other families in default across the country, Tio Paulinho chose to secure the continuation of his newly developed lifestyle, a decision that highlighted his perceived responsibilities both as a dignified citizen and as a respectable consumer of the house.

Tio Paulinho talked exhaustively about the implications of Rodrigo's decision to replace the company providing administrative and security services. Residents were now asked to help as services relied on their willingness to team up, to clean common areas, and to pay for maintenance products. Downsizing would make it possible for the condominium to save US $\$ 2,000$ a month, therefore compensating for the bloating default rates. Within each of the eight towers of the complex, residents organized to make improvements and to handle problems. Tio Paulinho's team installed aluminum structures over stairs to prevent premature wear and fenced outside barbecue areas against roughhousing.

"We have a really nice guy, they called him the postman," Tio Paulinho carried on (interview, November 24, 2016). "He has been planting flowers and coconut trees all along the sidewalk. He is wonderful." His message was clear: "This is our estate, our heritage. We want to make ours a better place." Tio Paulinho was contrasting such efforts to the widespread images of deprivation and hopelessness advertised by media outlets about Minha Casa Minha Vida projects. "We are trying to improve our space. With time, it will be."

Perhaps the condominium's endpoint was still up for grabs. It nonetheless materialized into everyday journeys - both collective and individual - toward improvement. Group-based activities included revitalizing common areas, collecting small sums of cash [vaquinhas], and directly negotiating with suppliers. As providers improved the quality of services, Tio Paulinho's unblinking eyes remained faithful to his right to "demand [cobrar]": "I told the new gatekeepers: Don't get distracted from your job, and don't leave the sentry box! It was constructed to keep you wary of the outside!" (interview, November 24, 2016).

Yet, Tio Paulinho also knows how to make technology fit into existing forms of sociability. From inside his apartment, he monitors the gate and the flux of people. Whenever he has something to say, he will now communicate through the doorbell phones. Sometimes he will receive prank calls from other neighbors. Clever, he learned how 


\section{Kopper}

to spot them through the crevice of the window. "If there is nobody at the gate, I don't pick up the phone," he joked (interview, November 24, 2016).

\section{Middle-class sensorial}

It was an amassing sense of curiosity and experimentation — with the ubiquity of technology and materialities - that drove Tio Paulinho into new territories of well-being and comfort. Indeed, both Rodrigo and Tio Paulinho were well acquainted with the empirical obstacles in the way of bringing their ideals to life. But rather than seeing them as insurmountable limits, such appreciation made them keenly sensitive to the learning curves and unpredictable usages embedded in people's own relation to infrastructure. Attentive, like anthropologists to ways technology is indigenized and attending to the uncertainties and instabilities of objects themselves (Larkin 2008), they opened new experiential spaces for materialities to settle within existing sociocultural schema.

The quest for the good life led by Rodrigo and Tio Paulinho and instantiated by the ubiquity of infrastructures suggests that we take seriously the roles of aspiration, experimentation, and subject making in the ethnographic study of class mobility. Conventional approaches to the subject, drawing on hierarchical concepts of stratification and distinction (Bourdieu 1984, 1987), have called attention to the ever-elusive quality of middle-class formations in Latin America. In his historical account, Brian Owensby (1999) documented the coming together of a new Brazilian identity in the period between 1920 and 1950 in Rio de Janeiro and São Paulo. Drawing from a myriad of documented sources, he argued that middle class as perceived in public culture is ultimately tied to the consolidation of a developmental state ideology.

Conversely, Maureen O'Dougherty (2002) explored the role of consumption in the enactment of middle-class identities. Spanning the period of Brazil's inflation crisis, she documented how a middle-class language emerged as a constellation of self-qualifying practices aimed at distinguishing themselves from both lower and upper classes. Brazilian anthropologist Gilberto Velho $(1973,1987)$ wrote in a similar vein about what makes middle-class claims distinctive as both an identity and a practice deeply entrenched in consumption and familial prestige. He drew on Bourdieu's $(1980,1984)$ concept of field of possibilities to ethnographically analyze how paths for upward mobility and social reproduction crystallized amid urban white collar workers in Rio de Janeiro.

While these readings track the shifting and contradictory landscapes under which middle-class projects emerged as sociohistorical realities, they tend to overlook the multiscalar and joint circuits-technological, informational, interventional, political, economic, and subjective - in which middle-class worlds emerge and disappear and are continuously woven together. Middle-class formations certainly reflect particular socioeconomic conditions of possibility under which flexible relationships between consumption and production, citizenship and identity, crystallize (Heiman, Freeman, and Liechty 2012).

Yet an ethnography of the middle class as a lived and experiential category would also consider the particular imaginative horizons through which distinction and belonging, hierarchy and aspiration, human becoming and materiality, are woven into action. This approach is illustrated by recent ethnographies that call for intermediate concepts of class (Liechty 2002; Schielke 2015) and inequality (Mitchell 2017). To apprehend processes of stratification at their local, national, and global levels, they sway between broad economic/historical/sociological narratives and the experiences, languages, and material affects of people directly impacted by it.

Chronicling the contentious design and implementation of surveillance technologies in the aftermath of a housing project caused me to become attentive to how objects and materials pervade middle-class affects. They reveal the extent to which labor, consumption, and future making rely on — and stabilize around - the ubiquity of materialities. These porous infrastructures do not simply operate as vessels of culture or as actants with agency of their own (Ingold 2012; Latour 2014); rather, they function as social connectors congealing systems of political and economic rationality and as vectors of desire and possibility (Anand 2017; Larkin 2013; Von Schnitzler 2013). 
Charting the material temporalities of the house - the textures of its formation, flux, and transformation - we can apprehend how life chances and imaginations intersect with, and leak from, the workings of planned infrastructures.

These tangled worlds of desire and materials - albeit fragile or unruly - are woven into communities of belonging and well-being through the workings of a class sensorial: a topography of images and affects through which class mobility is experienced and located in time and space. Consider, for example, Rodrigo's indirect comparisons to upper-middle-class high-rises and Tio Paulinho's narrative dislocations to a past where "there was no class." Here the imagined "Others" are not situated "above" and "below" the speakers - as in an abstract and hierarchical stratification system. Rather, they emerge as moving positionalities within a horizontal field of forces - the rich neighborhoods and the hills, topographies of a "before" and an "after." These aspirational experiments with past and future tropes of infrastructure thus reveal ideals of the good life that are both linked to a wider constellation of interclass imaginaries and seek to transcend them.

This class sensorial also sheds light on the complementary mechanics of distinction and belonging behind the efforts of Rodrigo and Tio Paulinho to make abstract concepts such as "security" and "inclusion" tangible. On one hand, the collective cultivation of surveillance infrastructures speaks of people's desire to be included in a consumers' society through their efforts to remake the built environment and reclaim access to the city. While this pursuit produces social distinctions ingrained in space, such distinctions are lived not as the enactment of interclass contours but as moral and aspirational discontinuities through which new senses of dignity and respectability stabilize.

These ever-changing dynamics of inclusion and exclusion, distinction and aspiration, past and future, call for a cartographic approach to class mobility, to the extent that a cartography is the emerging patchwork of imagined places and lines of flight that lend infrastructures a sense of belonging, both to the city and to one's own becoming. The cartography of this sensorial is best equipped to capture the intermediary scales and dual temporalities of historical/political/economic/spatial transformation and human becoming through which a politics of class mobility gains traction in the aftermath of urban interventions.

Constantly on the verge of collapsing, the material interventions honed by Rodrigo and Tio Paulinho hinged on their ability to be adapted, converted, and reframed according to the contingencies of the here and now. In this process, new temporary collectives of citizen-consumers kept aspirations afloat and gravitating toward centers of normalcy and respectability - human trajectories revealing the malleability and frailty of middle-class worlds and its perennial imbrication in dynamics of citizenship and consumption.

\section{Final words: A future yet to come}

In the everyday assemblages of Minha Casa Minha Vida, it was the material promise of the house and its objects that kept people like Rodrigo and Tio Paulinho waiting. Soon enough, this unique embroilment of opportunity and personal desire developed into the central goal of the housing association itself. Rodrigo and Tio Paulinho grew into conscious and respected leaders, drawing from their own experiences to persuade other common citizens of the benefits of striving to own their first homes. In the everyday workings of these model citizens, moral contrasts between the deserving and undeserving poor gained traction as part of a wider landscape of material citizenship under way. In the circulation of such stories of self-improvement, hope was reworded into a collective platform for human becoming. As subjectivizing devices (Fassin 2012, 80), they guided collectives of citizen-consumers into new paths for upward mobility from within the premises and promises of the housing program.

Mediated by infrastructures like gates and doorbell phones, material citizenship crystallized as individual hopes intertwined with emerging - yet also ephemeral - collectives of citizen-consumers. For some, homeownership simply represented the guarantee of stability, privacy, and access to credit and consumption: an enabling window into a future of movement and possibility. Yet, for others, material ubiquity was a testimony to how ever-elusive middle-class worlds continuously rise from poverty, eschew oblivion, and coalesce with place making. 


\section{Kopper}

Stuck at the gate, trailing its flux, I gained a sense of the kinds of movements and porosities that device helped to unfetter. It became clear why locals insisted on referring to the so-called gate-keeper as "vigilante." As a wary, eagle-eyed observer with discretionary powers, his make-believe task was to craft a separation between the dwellers and the shadows of their own past. Yet, as Dona Maria's case points out, this task was ever complicated by baffling rumors of robberies and personal favoritism. Deferring criticism kept personal hopes alive and the homeownership dream ongoing. Cast away from the hills and their dubious moralities, the promises of porous infrastructures would actualize as people engaged in temporary collectives and paved their way to new possibilities for upward mobility.

Throughout the article, I documented how ideas of securitization and fortification gained traction in the design and implementation of surveillance and security apparatuses by collectively organized residents of a housing project in southern Brazil. Transitioning between intimate and public registers, present and past recollections, I trailed the enmeshment of personal ideals of upward mobility and their development into collective figures of thought in the local machineries of the housing program. I showed how, in the everyday politics of waiting and hoping for the first homeownership, desires for infrastructure became the substance of emerging - yet also ephemeral - collectives of consumer-citizens.

Fleshing out the symbiosis of subjectivities and transformed architecture led me to move beyond hierarchical and exclusionary notions of middle class. Instead, I problematized a processual, horizontal, cartographic, and encompassing middle-class sensorial — one that restitutes immanence and unfinishedness to life worlds and desire (Biehl and Locke 2017), while capturing larger constellations of historical and spatial change under way. Unearthing the interjacent dynamics of distinction and belonging, hierarchy and aspiration, past and future, the middle-class sensorial illuminates everyday journeys toward territories of dignity, belonging, and respectability.

\section{Acknowledgments}

An early version of this article was presented at the 116th American Anthropological Association (AAA) annual meeting in Washington, DC. I would like to thank the Max Planck Institute for the Study of Societies, Cologne, and the Center for Metropolitan Studies, São Paulo, for providing ideal intellectual and infrastructural conditions to develop the reflections presented in this text. I am grateful to the São Paulo Foundation, the Coordination for the Improvement of Higher Education Personnel, and the Humboldt Foundation for their financial support. I also thank the editor and reviewers of Economic Anthropology; their insightful comments helped me improve the final version of this article.

\section{Notes}

1 Mortgages span over a period of ten years. Because low-income families partaking in the program are allowed by law to compromise only $5 \%$ of their domestic income with mortgage payments, governmental subsidies could represent up to $90 \%$ of the property cost.

2 Recent reports, however, point to the reproduction of long-standing patterns of peripheralization (Cardoso and Lago 2013) and financialization (Rolnik 2015) in Minha Casa Minha Vida initiatives.

3 Procon is a leading entity in the protection of consumers' rights in the country. Established in 1970, it is responsible for providing information and guiding consumers through their complaints.

\section{References}

Anand, Nikhil. 2017. Hydraulic City: Water and the Infrastructures of Citizenship in Mumbai. Durham, NC: Duke University Press. Biehl, João, and Peter Locke, eds. 2017. Unfinished: The Anthropology of Becoming. Durham, NC: Duke University Press.

Bourdieu, Pierre. 1980. Le Sens Pratique. Paris: Minuit.

_ 1984. Distinction: A Social Critique of the Judgment of Taste. Cambridge, MA: Harvard University Press.

1987. "What Makes a Social Class? On the Theoretical and Practical Existence of Groups." Berkeley Journal of Sociology 32(1): 1-18.

Caldeira, Teresa. 2000. City of Walls: Crime, Segregation, and Citizenship in São Paulo. Berkeley: University of California Press.

Cardoso, Adauto, and Luciana Correa do Lago. 2013. "O Programa Minha Casa Minha Vida e Seus Efeitos Territoriais." In O Programa Minha Casa Minha

Vida e Seus Efeitos Espaciais, edited by Adauto Cardoso, 7-16. Rio de Janeiro: Letra Capital.

Crapanzano, Vincent. 2004. Imaginative Horizons: An Essay in Literary-Philosophical Anthropology. Chicago: University of Chicago Press. 
Das, Veena, and Deborah Poole. 2004. "States and Its Margins: Comparative Ethnographies." In Anthropology in the Margins of the State, edited by Veena Das and Deborah Poole, 3-34. Santa Fe, NM: School of American Research Press.

Fassin, Didier. 2012. Humanitarian Reason: A Moral History of the Present Times. Berkeley: University of California Press.

Ferguson, James. 2015. Give a Man a Fish: Reflections on the New Politics of Distribution. Durham, NC: Duke University Press.

Fischer, Edward F. 2014. The Good Life: Aspiration, Dignity, and the Anthropology of Wellbeing. Palo Alto, CA: Stanford University Press.

Gupta, Akhil. 2012. Red Tape: Bureaucracy, Structural Violence, and Poverty in India. Durham, NC: Duke University Press.

Heiman, Rachel, Carla Freeman, and Mark Liechty. 2012. "Introduction: Charting an Anthropology of the Middle Classes." In The Global Middle Classes:

Theorizing through Ethnography, edited by Rachel Heiman, Carla Freeman, and Mark Liechty, 3-30. Santa Fe, NM: School for Advanced Research Press.

Hetherington, Kregg. 2012. "Promising Information: Democracy, Development, and the Remapping of Latin America." Economy and Society 41(2): $127-50$. Hirschman, Albert O. 1970. Exit, Voice, and Loyalty: Responses to Decline in Firms, Organizations, and States. Cambridge, MA: Harvard University Press.

Hull, Matthew S. 2012. Government of Paper: The Materiality of Bureaucracy in Urban Pakistan. Berkeley: University of California Press.

Ingold, Tim. 2012. "Trazendo as Coisas de Volta À Vida: Emaranhados Criativos Num Mundo de Materiais." Horizontes Antropológicos 18(37): 25-44.

Klein, Charles H., Sean T. Mitchell, and Benjamin Junge. 2018. "Naming Brazil's Previously Poor: 'New Middle Class' as an Economic, Political, and Experiential

Category." Economic Anthropology 5(1): 83-95. https://doi.org/10.1002/sea2.12104.

Kopper, Moisés. 2016. "Arquiteturas da Esperança: Uma Etnografia da Mobilidade Econômica no Brasil Contemporâneo." PhD diss., Universidade Federal do Rio Grande do Sul.

Kopper, Moisés, and Arlei Sander Damo. 2018. "A Emergência e Evanescência da Nova Classe Média Brasileira." Horizontes Antropológicos 24(50): 335 -76.

https://doi.org/10.1590/S0104-71832018000100012.

Larkin, Brian. 2008. Signal and Noise: Media, Infrastructure, and Urban Culture in Nigeria. Durham, NC: Duke University Press.

. 2013. "The Politics and Poetics of Infrastructure." Annual Review of Anthropology 42: 327-43. https://doi.org/10.1146/annurev-anthro-092412-

155522.

Latour, Bruno. 2014. "Agency at the Time of the Anthropocene." New Literary History 45(1): 1-18. https://doi.org/10.1353/nlh.2014.0003.

Liechty, Mark. 2002. Suitably Modern: Making Middle-Class Culture in a New Consumer Society. Princeton, NJ: Princeton University Press.

Mathews, Gordon, and Carolina Izquierdo. 2009. Pursuits of Happiness: Well-Being in Anthropological Perspective. New York: Berghahn Books.

Mitchell, Sean T. 2017. Constellations of Inequality: Space, Race, and Utopia in Brazil. Chicago: University of Chicago Press.

O'Dougherty, Maureen. 2002. Consumption Intensified: The Politics of Middle-Class Daily Life in Brazil. Durham, NC: Duke University Press.

Owensby, Brian P. 1999. Intimate Ironies: Modernity and the Making of Middle-Class Lives in Brazil. Stanford, CA: Stanford University Press.

Rolnik, Raquel. 2015. Guerra dos Lugares: A Colonização da Terra e da Moradia na Era das Finanças. São Paulo: Boitempo.

Schielke, Joska Samuli. 2015. Egypt in the Future Tense: Hope, Frustration, and Ambivalence before and after 2011. Bloomington: Indiana University Press.

Velho, Gilberto. 1973. A Utopia Urbana: Um Estudo de Antropologia Social. Rio de Janeiro: Jorge Zahar.

1987. Individualismo e Cultura: Notas para uma Antropologia da Sociedade Contemporânea. Rio de Janeiro: Jorge Zahar.

Von Schnitzler, Antina. 2013. "Traveling Technologies: Infrastructure, Ethical Regimes, and the Materiality of Politics in South Africa." Cultural Anthropology

28(4): 670-93. https://doi.org/10.1111/cuan.12032. 